\title{
Barricades and Boulevards: Material transformations of Paris, 1795-1871
}

\section{Carl Douglas}

"Destroying and constructing are equal in importance, and we must have souls for the one and the other". ${ }^{1}$

Large-scale urban violence is a tumultuous, messy and distressing affair. Materials and patterns of everyday life are blown apart. Amongst death and disarray, important spatial operations that take place in urban conflict are easily overlooked. However, the construction of street barricades and boulevards in Paris between 1795 and 1871 transformed the city. The struggles over these transformations can be described as both the disruption and the policing of what Rancière calls the "distribution of the sensible". ${ }^{2}$

The barricades built in the streets of Paris in the revolutionary years that followed the Great Revolution of 1789, and closed with the suppression of the Paris Commune in 1871, were not the first or the last artefacts of urban insurgency. Nor was Paris the only city in history - even European history - to be barricaded. However, in Paris, barricading became a revolutionary technique, the development and decline of which can be traced with some precision. Barricading served complex social purposes, of which defense was only one, and not always the most significant. Thus, barricades are also an ephemeral city-scale architecture occasioned by, and changing, the social. ${ }^{3}$

\section{History and Tectonics of a Rubbish Heap}

At first, the Parisian barricades were temporary barriers, or walls erected quickly across streets. They were built by anonymous groups of insurgents from whatever loose materials could be found nearby: carts, furniture, barrels and, most typically, paving stones torn up from the roadway. They were constructed en masse. In July 1830 there were over 4,000 barricades; in June 1848 there were as many as 6,000 .
I. Paul Valéry, quoted in Pallasmaa (2003: 6).

2. For Rancière's political philosophy, see Disagreement: Politics and Philosophy (1998), and The Politics of Aesthetics (2004), which contains a useful glossary of Ranciére's terms.

3. The barricades' history is in some ways distinct from the history of ad-hoc fortifications (trenches, seige works, emplacements) in general. For the barricades, see Corbin and Mayeur (1997) and Mark Traugott (1993). In addition, nearly all historical accounts of the French revolutionary period mention the barricades, but few consider their significance in a sustained manner. For the general historical context, see Hobsbawm (1962) and (1975). 


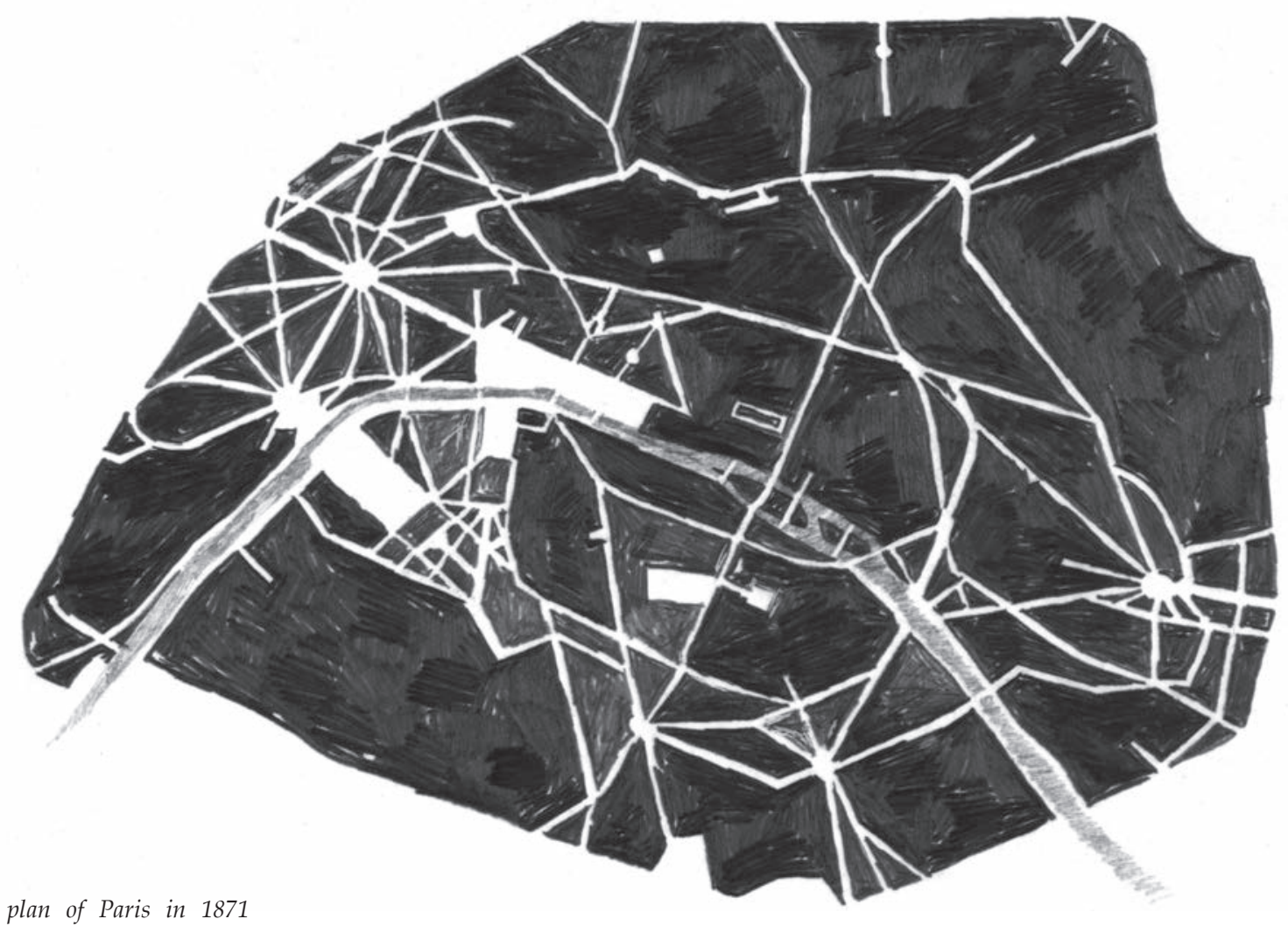

Schematic plan of Paris in 1871 following Haussman's works.

4. The French uprising of 1848 sparked others in cities across Europe, incluing Brussels, Vienna, Berlin, Munich, Milan, Naples, Budapest, Frankfurt, Prague and Dresden.

5. For Haussmann, see Jordan (1995). The barricades and Haussmann's boulevards are two of the key coordinates in Walter Benjamin's study of the emerging spaces and structures of the bourgeoisie. See Benjamin (1999) and (1986).
The first recorded instance of barricading in Paris occurred in 1588, when the popular Comte Cossé de Brissac lead Parisians in a rebellion in response to the posting of soldiers in the streets of the city. Chains were sometimes used to close streets to traffic, and these points of closure were reinforced with barrels (barriques) filled with stones to restrict military movement. In 1648, the arrest of a popular politician lead to the erection of over a thousand barricades in the city. Thereafter, barricades did not recur for nearly 150 years, playing no part in the Revolution of 1789 . When they did reappear, with the Jacobin uprising of 1795 , it was in a different context. While civil disobedience had previously been used as a way of gaining leverage over political leaders, the intention was now the complete overthrow of the state. Between 1795 and 1871, historian Mark Traugott records twenty-one instances of barricading (1993: 315). The most famous of these incidents were the July Days of 1830 (portrayed by Delacroix in his 1830 painting La Liberté guidant le peuple), and the revolutions of February and June 1848. According to Traugott (316), while barricading, by 1848, had achieved "a genuinely international status as a tactic of revolt", it was already losing effect in the face of mobile artillery and improving military tactics. ${ }^{4}$ In the streets of Paris, the last time barricades were used in a major way was during the Paris Commune of 1871, when the socialist government of the city declared itself independent of Versailles. Although barricades continued to be used in other cities in Europe, including Barcelona and Berlin, and reappeared in Paris in 1945 and 1968, barricading as a technique had ceased to be decisive in urban insurgency.

Between 1795 and 1871, when barricading was a common revolutionary tactic, France alternated between revolutionary governments and periods of centralized imperial rule. George-Eugène Haussmann's famous urban restructuring of Paris, which occured during one of the latter periods - the Second Empire of Louis Napoleon (1852-1871) - was, in part, an explicit response to the threat of barricades. ${ }^{5}$ Haussmann cut wide new boulevards through the fabric of old Paris, 


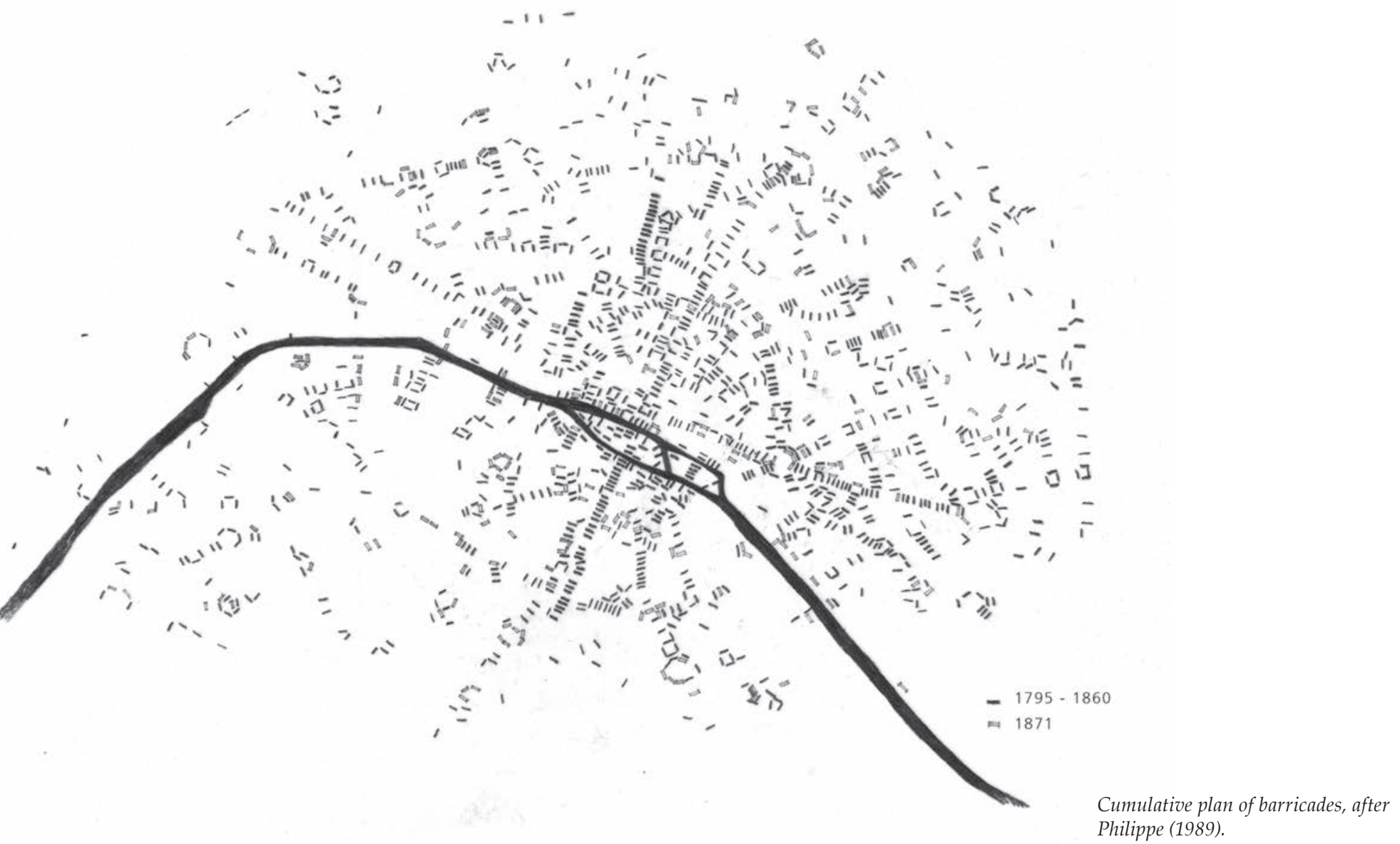

buying and demolishing whatever was in the way, setting up axes and monuments, and clearing space around buildings like Notre Dame and the Palais du Louvre. By cutting into the body of the city with his boulevards and promoting unimpeded circulation, Haussmann hoped not only to alleviate the social pressures which produced unrest, but also to make the construction and defense of barricades impossible.

Barricades and boulevards are conflicting regimes of materials, spaces and performances. Architecture does not merely mirror social relations: it acts to produce them. Henri Lefebvre describes how the production of social relations is already the production of a space for those relations, through practices and representations. Instead of acting as a container, within which all kinds of relations could take place, space defines subjects and the range of possible relations they can have with one another (Lefèbvre, 1991). Walter Benjamin recognised the reconstructing of the civic subject in the Haussmannization of Paris. He writes, only partly in jest: "The widening of the streets, it was said, was necessitated by the crinoline" (1999: 133). In Haussmann's Paris, the bourgeois subject of the boulevards is opposed to the placeless labourer, who does not truly belong to the city; and the reconfiguration of the city's materials and spaces reconfigures social relations.

It would be too simple to contrast Haussmannization, as the imposition of centralized state law on the city, with the barricades as exuberant or violent disobedience to that law. In his "Critique of Violence" (1986b), Benjamin argues that law and order cannotbeopposed to violence. Rather, they mustbe seen as essentially violent themselves. Law is even an essential condition of violence, and violence is not the absence or failure of law; rather, it is a law being imposed: "Lawmaking is power making, and, to that extent, an immediate manifestation of violence" (295). In Benjamin's thought, the opposition of the destructive, violent space of the 
6. "Man does not live by words alone; all 'subjects' are situated in a space in which they must either recognize themselves or lose themselves, a space which they may both enjoy and modify" (Lefebvre, 1991: 35). barricades to the lawful, constructive space of Hausmann's Paris is false. In fact, he notes that Haussmann referred to himself as an "artist-demolitionist" (1991: 128), and gathers Second Empire sources who describe the scale of destruction involved in Haussmannization. Similarly, the violence of the barricades contains the violence of a new lawmaking. Destruction and construction are equally capable of violence insofar as they both mark the operation of law. If Haussmannization and the barricades are both recognized as material and spatial transformations of the city, then they must both be appreciated not only for their violence, but as conflicting impositions of law.

Jacques Rancière articulates a theory of politics which is Benjaminian in its understanding of conflict. The city's materials and spaces do not simply bear the imprint of politics, and the city is not a neutral surface which is only inflected and marked politically. Instead, the very perception of there being a city - what a city is, how it is assembled, who inhabits it - is the result of "a distribution of spaces, times, and forms of activity" (Rancière, 2004: 12). If lawmaking is conflict for Benjamin, for Rancière, conflict is a dispute over the distribution of what can be perceived within a given regime. This distribution of the sensible (le partage $d u$ sensible) is described by Rancière as an "implicit law" (1998: 29).

Rancière's distribution of the sensible closely parallels Henri Lefebvre's production of the space of social relations. The production of space is the production of the ground against which social relations can be seen to resolve. Social relations, argues Lefebvre, cannot exist except in and through the production of space. ${ }^{6}$ For Rancière, social relations are rendered conceivable only through the distribution of what can be sensibly apprehended.

The work of maintaining a certain existing distribution of the sensible is carried out by what Rancière calls "the police":

The police is essentially, the law, generally implicit, that defines a party's share or lack of it ... The police is thus first an order of bodies that defines the allocation of ways of doing, ways of being, and ways of saying ... Policing is not so much the 'disciplining' of bodies as a rule governing their appearing, a configuration of occupations and the properties of the spaces where these occupations are distributed (1998: 29).

Benjamin also describes the role of the police in upholding the law, not simply enacting laws: "Rather, the 'law' of the police really marks the point at which the state ... can no longer guarantee through the legal system the empirical ends that it desires at any price to attain" (1986b: 287). Policing marks the edge of law, the line at which practices or bodies are brought under law.

Following Benjamin, if we see the barricades and the boulevards as equally violent practices of law-making and, following Rancière, we see lawmaking as the policing of a distribution of the sensible, then new questions can be asked of the actual, material transformations of Paris between 1795 and 1871. How did barricades and boulevards redistribute materials and spaces? Thus, what became visible? How did the lawmaking and share-allocating roles of the police work on the transformations of Paris in the period in question? 
The following sections stage a conflict between the barricades and the boulevards, with a view to the performative nature of the barricades in their historical context: the ways in which the material configurations of barricades and boulevards produce certain kinds of perception; and how perception renders subjectivity.

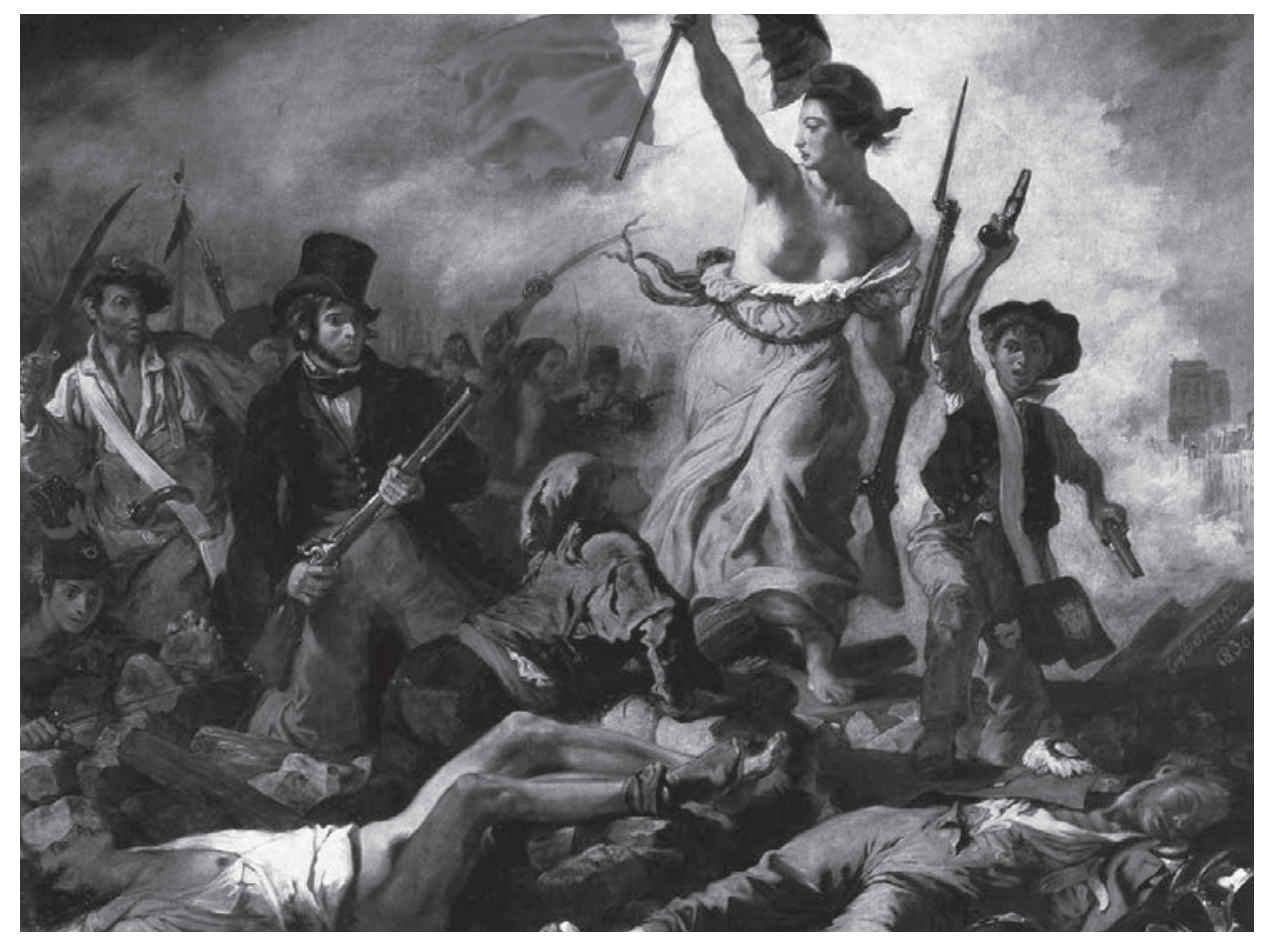

Eugène Delacroix, 'La Liberté guidant le peuple', 1830.

\section{Historical Performances}

Romantic images of the barricades, like Delacroix's La Liberté guidant le peuple, reflect the important symbolic role of the barricades. An obvious observation about Delacroix's painting is that the greatest mass in the image is made up of human bodies: heads, arms and bayonets blend into the dim depths; bodies anchor the image on the left, underline it, and are silhouetted against the smoke in the centre. Architecture, as materiality, is reduced to an emblematic presence: in the distance, at the far right of the frame, a row of houses and the towers of Notre Dame emerge from the smoke. Human figures are not constrained or enclosed by buildings, even though the streets of Paris in the1830's werenotoriously narrow. The paved surface of the road is visible only along the bottom. The barricade itself is barely more than knee-high and mostly obscured. Some paving stones are heaped up with pieces of lumber, but they certainly do not form a wall. There is no sense that the barricade is a blockage; rather, it is little more than a dais for Liberty to stand on.

Narrative accounts of uprisings suggest that a barricade was a space in which dramatic events were performed. Great anecdotal importance is attributed to what happened 'on the barricades', where figures harangue the mob, and people find noble or appalling deaths:

Baudin stepped forward to the barricade and said, "Stay there a minute longer, my friend, and you'll see how a man dies for 
7. See Traugott (1978), in which he sets out his position regarding social movements; and (1985) for an example of his empirical method.

8. In one anonymous photograph, taken on the Rue des Amandiers, we see a barricade of pavingstones, covered with earth dug out from in front of the mound, and with castellations for the cannons. All along the barricade stand men in a semi-regular uniform. To the far right of the frame, observers have gathered to see this spectacle. The camera provided a means to expand the symbolic reach of the barricades. By posing for photographs, the Communards reinforced the performative role of the barricades. Jeannene Pzyblyski writes "the Communards posing on the barricades explicitly laid claim to the theatricality that is intrinsic to photographic reality, to the performativity that is the counterpart to its opticality" (Przyblyski, 200I: 64).

A barricade of the Paris Commune, on the rue des Amandiers, 1871. twenty-five francs." A column of soldiers approached from the Bastille and rushed the barricade. Baudin was killed (Duveau, 1967: 163).

Thus, the barricades were rhetorical constructions, not only military-strategic devices. Friederich Engels, in his introduction to Marx's The Class Struggles in France, 1848-1850, considers the successes and failures of urban insurgency, and concludes:

Even in the classic time of street fighting, therefore, the barricade produced more of a moral than a material effect. It was a means of shaking the steadfastness of the military. If it held out until this was attained, then victory was won; if not, there was defeat (1934: 14).

According to Engels, the barricades' effectiveness declined partly because "the spell of the barricade was broken". Whereas before, soldiers facing the barricades would be convinced that they were not merely facing a gathering of individuals, but a manifestation of 'the people', once the rhetorical spell was broken, they saw only "rebels, agitators, plunderers, levelers, the scum of society" (14).

Traugott consciously seeks to lift this 'spell', in order to reveal the production of social movements from collective actions. ${ }^{7}$ He argues that barricading became, with each repetition, an increasingly ritualised act loaded with "symbolic and sociological functions" (1993: 317). Each new instance of barricading was also a re-enactment of previous barricades. During the Paris Commune, the Communards were eager to have themselves photographed with their barricades. In doing this, they reinforced the spectacular and performative nature of their constructions. ${ }^{8}$

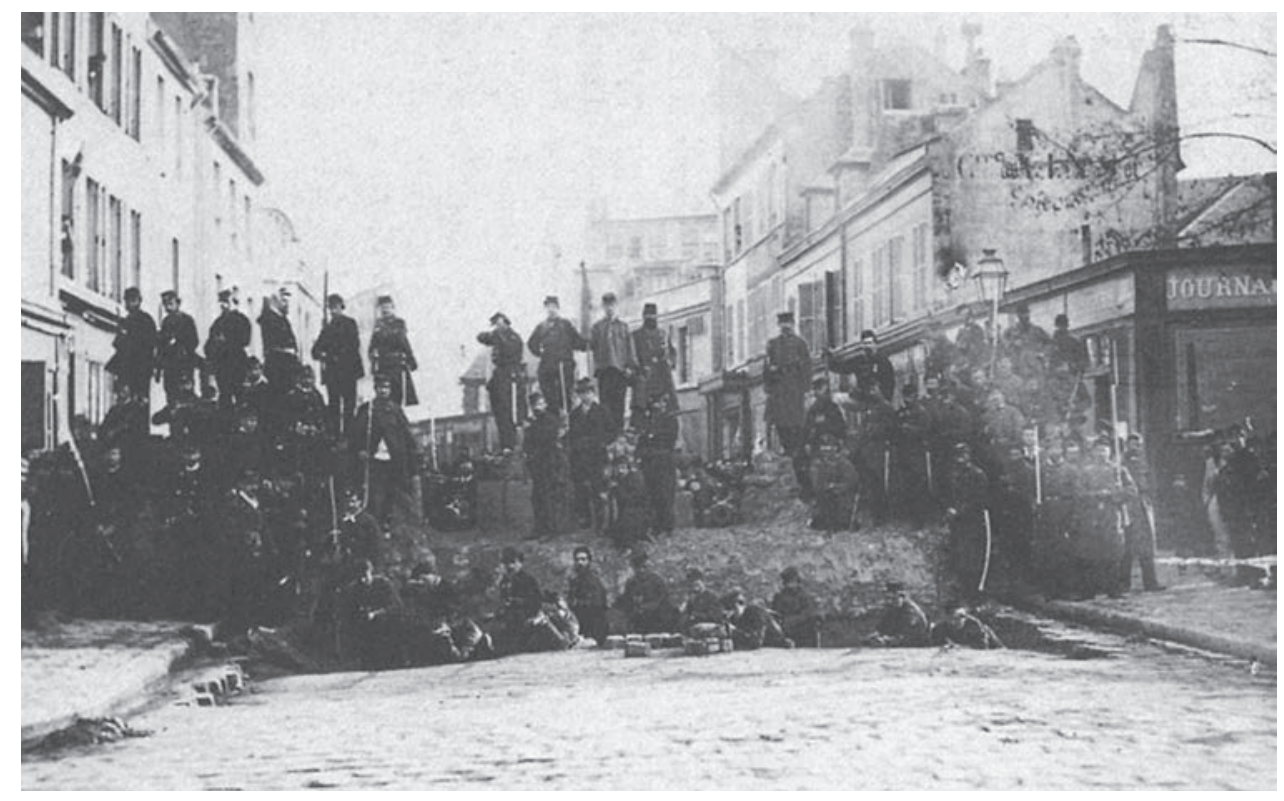

Haussmann spent the years leading up to 1871 converting Paris into a network of linked monuments, which were cleared and set apart, freed from their engagement in the fabric of the city. An image space was created for viewers to stand back and see the monuments as free-standing sculptures: Paris became a monumental gallery. In contrast, the barricades aligned more closely with 
Benjamin's description of the new arts - the mass media: they were reproducible, and their ability to function even depended on their reproduction. For Benjamin, like architecture generally, they were perceived in a state of distraction, as a background or stage for events: "A man who concentrates before a work of art is absorbed by it ... In contrast, the distracted mass absorbs the work of art" (1999: 232). As performance, the barricades were oriented towards the masses, whose interpretation and participation was invited. In contrast, the boulevards divided the city into segments, in which preselected art objects could be apprehended with the gaze of the gallery patron.

\section{Material Constructions}

Victor Hugo's Les Misérables (1862) includes a fictionalized account of an uprising and descriptions of the monumental barricades of the 1848 June Days, of which Hugo was an eyewitness. The Saint-Antoine barricade was three storeys high and seven hundred feet long:

It ran from one end to the other of the vast mouth of the Faubourg - that is to say, across three streets. It was jagged, makeshift and irregular, castellated like an immense medieval survival ... Everything had gone onto it, doors, grilles, screens, bedroom furniture, wrecked cooking stoves and pots and pans, piled up haphazard, the whole a composite of paving-stones and rubble, timbers, iron bars, broken window-panes, seatless chairs, rags, odds and ends of every kind and curses ... The Saint-Antoine barricade used everything as a weapon, everything that civil war can hurl at the head of society ... a mad thing, flinging an inexpressible clamour into the sky... It was a pile of garbage, and it was Sinai (Hugo, 1982: 989-990).

An 1848 military reconnaissance report similarly notes mounds up to five metres wide and of widely varying heights (Price, 1996: 90). Their basic material was the street paving, which was torn up and piled, stacked or mounded. Mounding was typically supplemented by piling up whatever material was to hand: construction materials, furniture, rubbish, carriages, and the whole of Hugo's heterogeneous litany. Sometimes, barricades stretching part-way across the street were staggered, permitting revolutionaries to pass without needing to climb over. The patch of bare earth left by tearing up paving stones was occasionally dug out to form a pit in front of the barricade. Some barricades were built as walls with eyelets, firing slots, or larger holes for improvised pipe-cannons and appropriated artillery. ${ }^{9}$

In contrast, the two-storey barricade of the Faubourg de Temple was built with military precision:

A view from above enabled one to ascertain its thickness: it was mathematically even from top to bottom. Its grey surface was pierced at regular intervals with almost invisible loopholes, like dark threads. The street bore every sign of being deserted: all doors and windows were closed. The wall, erected across it, a motionless, silent barrier, had made of it a cul-de-sac in which no person was to be seen, no
9. For the construction of the barricades, see Corbin and Mayeur (1997), Price (1996: 90), descriptions collected by Benjamin (1999: 120-147), and photographs collected by Pryzblyski (2001: 54-78). 
sound heard. Bathed in the dazzling June sunshine, it had the look of a sepulchre ... immaculate in design, flawless in alignment, symmetrical, rectilinear and funereal, a thing of craftsmanship and darkness (Hugo, 1982: 991).

For Hugo, these two constructions expressed two aspects of the revolution: defiance and silence; the dragon and the sphinx; "a roaring open mouth" and a mask. These oppositional pairs align with the two poles of barricade construction: the mound and the wall.

Barricades disrupt the proper relations of the city. Things are displaced and repurposed, weaponised and, as Hugo puts it, hurled at the head of society. Engravings of the fighting in the region of Saint-Antoine show the air filled with cabinets, tables, chairs and paving stones. On the second and third floors of buildings overlooking the barricade, armed insurgents took up position and fired or threw material down onto the heads of advancing troops. A network of supporting passages was established through gardens and houses, disused land and alleyways. Interior passages were made by breaking through the walls of the houses alongside the barricade, so barricaders could move up and down the street rapidly under cover.

Barricades and boulevards produced two distinct regimes of perception in the city. Under the regime of the barricades, the city became visible as a continuous field of material: a landscape. In 1915, Irish revolutionary James Connolly, recommending barricading as a tactic, argued that the city was, strategically, a landscape: "A mountainous country has always been held to be difficult for military operations owing to its passes or glens. A city is a huge mass of passes or glens formed by streets and lanes" (1915). Under the regime of the barricades, divisions into tenancies and properties were no longer respected. Space and materials were appropriated, shared and stolen as the barricaders converted the city into a continuous field of urban matter, to be traversed or tunnelled through. In view of the city as a continuous field, previously obvious partitions and distinctions suddenly appeared irrelevant, incomprehensible.

In the wake of 1848, the boulevards were the state power's forceful response to such disruption, reinforcing civic order and shoring up the existing distribution of the sensible. Everything was allocated its proper place in the new urban structure, a place determined according to imperial coordinates. If the distribution of the sensible acts to allocate places, to determine what is visible and invisible (what can be perceived or apprehended and what cannot), then how did the boulevards determine social relations? In his memoirs, Haussmann wrote with pride about having erased certain locations from Paris: the Rue Transnonain, site of a massacre in 1834, and the Rue de Rempart, where Haussmann himself had been caught in the fighting in 1830. In their place, his works made visible the sites of centralized power. The Rue de Rivoli, for example, was extended to form a broad road and a line of sight from the Courbevoie barracks to the Place de la Bastille in the region of Saint-Antoine, that hotbed of discontent. Visual axes and perspective served as focussing tools. On the boulevards, people were subjected to vanishing-points made to coincide with the monuments of power. A joke of the period was that the Avenue de l'Opéra was positioned to afford patrons a view of the Emperor's gatehouse (see Jordan 1995: 185-210). 
The new city privileged the shoppers in the arcades, the opera patrons and all who had leisure to stroll the boulevards. At the time of Haussmann's work, some described the latter as being like deserts. ${ }^{10}$ The new spaces of Paris - broad, open, gas lit - and particularly the new meeting-places, such as Charles Garnier's Opéra, not only made individuals visible, but showcased them.

Haussmann perceived the city as a body to be operated on. To him, civil unrest was an urban malaise, a sickness resulting from a cramped and insalubrious urban fabric. ${ }^{11}$ Under the fresh autocracy of the Second Empire, Haussmann cut strategic routes that separated out and surrounded troubled areas, relieved pressure points and alleviated density. The lines and crossings of the new boulevards set the parts of the city into proper relations. Long perspectives connected distant parts of the city into a well-defined figure. As the state took on the role of oversight and action, a distinction became apparent between those operating in the city, and those operating on the city. ${ }^{12}$

\section{Collective subjectivity}

On the other hand, the barricades produced a view of the city which rendered visible a collective subject, as a communal construction. The number and anonymity of the barricaders, and the speed at which barricades were constructed, lead to a tendency amongst historians to refer to instances of barricading as almost spontaneous eruptions: "barricades were springing up all over" (Duveau, 1967: 167). The barricades were not just individual structures but formed an architecture at the scale of the city. Their distributed nature and anonymity enabled those behind them to say ' $w e^{\prime}$ ' at an urban scale. During barricade construction, passers-by were each invited to contribute a paver. Construction became a means of engaging the disengaged, of converting observers into participants.

No wonder Haussmann was suspicious of the masses. A document from his office describes them as, "a floating mass of workers ... of nomad renters ... an accumulation of men who are strangers to each other, who are attracted only by impressions and the most deplorable suggestions, who have no mind of their own" (in Jordan, 1995: 217). To him, only cultured individuals counted as citizens of Paris, and he complained of the displaced masses "who compromise the signification of the vote by the weight of their unintelligent votes" (334). Since the masses could not articulate their democratic voice correctly, they were a burden on Paris, fouling up the democratic process. As long as people remained part of the"floating mass ... attracted only by impressions and the most deplorable suggestions" (217) and without a mind of their own, they could not appear as individuals.

Gustave Le Bon inaugurated one of the most influential nineteenth century theories of collectivity, crowd psychology, which arose from his studies of the Great Revolution of 1789. In The Crowd: A study of the popular mind (1895), Le Bon writes:

Under certain given circumstances, and only under those circumstances, an agglomeration of men presents new characteristics
10. Le Corbusier writes of Haussmann's reception by the Chamber of Deputies: "One day, in an excess of terror, they accused him of having created a desert in the very center of Paris! That desert was the Boulevard Sébastopol" (cited in Benjamin, 1999: 129).

II. "The urgency of urban renewal infused the language of critics and reformers - the discourse of salubrity, cleansing, aerating, movement - with political meaning. Paris was sick, moribund, suffocating" (Jordan, 1995: 185).

12. Haussmann "did not make a practice of visiting the various municipal projects except on ceremonial occasions, when he conducted the emperor or some visiting dignitary around a building site. His plans for the city were realized abstractly, geometrically, on a map. His working map was not a physical map of the city, with buildings and monuments depicted, but an abstract expression of the space occupied by Paris" (Jordan, 1995: 174-175). But all of Haussmann's labours could not prevent the barricades of the Paris Commune in 1871. "What Haussmann's destruction of the rabbit warren of streets in eastern Paris had done was transform barricades and urban insurrection from a cottage industry to a substantial and sophisticated undertaking" (Jordan 1995: 181). The barricades of the Commune clot the body of Haussmann's city, obstructing the flow of pedestrians, vehicles and commerce; and disrupting the structure of public and private space once again. On cleaning up after the barricades, see Chauvaud, 'L'élision des traces. L'effacement des marques de la barricade à Paris' in Corbin and Mayeur (1997: 267-28I). 
13. For crowd psychology in the nineteenth century, see van Ginneken (1992). very different from those of the individuals composing it ... A collective mind is formed, doubtless transitory, but presenting very clearly defined characteristics ... It forms a single being, and is subjected to the law of the mental unity of crowds (Le Bon, 2001: 4).

Le Bon regards the subjection of the individual personality to the psyche of the crowd as an actual physical effect. The body enters a primitive state of suggestibility close to hypnosis. By "the mere fact that he forms part of an organised crowd," a man descends several "rungs in the ladder of civilisation. Isolated, he may be a cultivated individual; in a crowd, he is a barbarian - that is a creature acting by instinct" (Le Bon, 2001: 19). A crowd attains its mental unity at the expense of individual civility and intelligence. It is an act of barbarism to resign one's individual will in order to participate in a crowd, and there is no communicating with a barbarian. Le Bon's theory of collectivity invalidated the voice and presence of collectives, and helped police the existing distribution of the sensible. ${ }^{13}$

Rancière refers to those who are assigned not merely a subordinate role in society, but the role of voicelessness, as the sans part - "the part of those who have no part"(Rancière, 1998: 9). The sans part are those rendered incomprehensible by a given distribution of the sensible. In the boulevards, it was for 'the mass' to play this role: there was no place assigned to collectives. 'The mass' was not strictly the poor, although the two often coincided (money being one of the key mechanisms for gaining purchase in the city and attaining the status of an individual). Although subordinate within the structures of Imperial Paris, the poor were thinkable as objects of charity, crime, or labour. It was the collective that was unthinkable, sans part, in the boulevards. The partition of the sensible, Paris' material urban elements, was distributed to assign places to individuals, not to masses or crowds. However, with the barricades, the collective, as sans part, rose and insisted on its ability to speak.

\section{The ends of barricading}

The barricades instituted an active, participatory and dynamic version of the city. In contrast, the boulevards policed a static and hierarchical order. The barricades were what Rancière calls a moment of politics, a disruption by the sans part of the distribution of the sensible that excludes them. The boulevards were on the side of the police, of the implicit law that reinforces the existing distribution of the sensible.

In staging the conflict of the two regimes here, they are compared on more or less equal terms. However, this is not fully representative of the situation. While Haussmann's regime persisted into the twentieth century, the regime of the barricades only ever lasted for short intervals. Sometimes these intervals ended with the overthrow of the state, and the substitution of an alternative order, and sometimes they were brought to an end by failure.

After 1871, the barricades' strategic function had lost much of its effectiveness. Although Haussmann's interventions had not been able to prevent barricading, 
they had certainly made the city less hospitable towards it. Also, military techniques and tools had improved. Few barricades could hold out against artillery and regular infantry. Nevertheless, the barricades maintained a symbolic afterlife in Communist writing and practice. Barricades always had a literal and strategic, as well as a metaphorical, performative function. By 1871, the balance had shifted significantly towards the metaphorical.

Metaphor exists in the passage from the literal to the figurative (see Goodman, 1968 , and Grey, 2000, for example). When meaning is carried over from a concrete context to a non-literal one, it disrupts the familiar and generates new perception. To remain effective, as Goodman puts it, "metaphor requires attraction as well as resistance" (69). It is only in the interchange between attraction and resistance, between the literal and figurative contexts, that metaphor enables us to see differently. In Rancière's thought, according to Brian Holmes, "the place-changing action of metaphor - one thing or person for another - is what allows the creation or extension of a community of speaking subjects" (Holmes, 2001).

In Rancièrian terms, the large-scale spatial contention in Paris in the nineteenth century was "a conflict over what is meant by 'to speak', and over the very distribution of the sensible that delimits the horizons of the sayable" (2004: 4). The conflict enacted between the barricades and the boulevards is a conflict over what 'the public' is: how it is visible, and what ability it is accorded to speak. This specific instance points to the role of architecture in general. What is it, if not the arrangement and distribution of spaces, times and forms of activity? Architecture engages in distributing and redistributing the sensible: making visible, audible, perceptible. The city is not merely a reflection of a political conflict that occurs at another level; and the ephemeral architecture of the barricades effected a redistribution of the sensible, of a material politics that was not merely the mirror of an abstract politics occurring elsewhere.

\section{References}

Benjamin, W. (1986). Paris, Capital of the Nineteenth Century. In Reflections: Essays, Aphorisms, Autobiographical Writings (E. Jephcott, Trans.). (146-162). New York: Schocken Books.

Benjamin, W. (1986). Critique of Violence. In Reflections: Essays, Aphorisms, Autobiographical Writings (E. Jephcott, Trans.). (277-300). New York: Schocken Books.

Benjamin, W. (1999). The Arcades Project (H. Eiland \& K. McLaughlin, Trans.). Cambridge: Belknap Press.

Benjamin, W. (1999). The Work of Art in the Age of Mechanical Reproduction. In Illuminations (H. Zorn, Trans.). (211-244).

Connolly, J. (1915). Street Fighting - Summary. Workers' Republic, 24 July 1915. Text available online at http://www.marxists.org/archive/connolly/1915/rw/stfight.htm

Corbin, A. \& Mayeur, J. (Eds.). (1997). La Barricade. Paris: Publications de la Sorbonne.

Duveau, G. (1967). 1848. The Making of a Revolution (A. Carter, Trans.). London: Routledge and Keegan Paul.

Engels, F. (1934). Introduction. Marx, K. The Class Struggles in France, 1848-1850. London: M. Lawrence. 
Grey, W. (2000). Metaphor and Meaning. Retrieved October 1, 2007, from http://www.ul.ie/ $\sim$ philos/vol4/metaphor.html

Goodman, N. (1968). Languages of Art: An Approach to a Theory of Symbols. Indianapolis: Bobbs-Merrill.

Hobsbawm, E. (1962). The Age of Revolution, 1789-1848. London: Random House.

Hobsbawm, E. (1975). The Age of Capital, 1848-1875. London: Random House.

Holmes, B. (2000). Hieroglyphs of the Future: Jacques Rancière and the Aesthetics of Quality. Cabinet Magazine (4, Fall). Retrieved October 1, 2007, from http://www.cabinetmagazine. org/issues/4/Hieroglyphs.php

Hugo, V. (1982). Les Misérables (N. Denny, Trans.). London: Penguin Books.

Jordan, D.P. (1995). Transforming Paris. The Life and Labours of Baron Haussmann. New York: Free Press.

Le Bon, G. (2001). The Crowd. A study of the popular mind. (B. Miall, Trans.). Kitchener: Batoche.

Lefèbvre H. (1991). The Production of Space. (D. Nicholson-Smith, Trans.). Oxford: Blackwell.

Pallasmaa, J. (2003). Constructing Essences. Pamphlet Architecture 25. New York: Princeton Architectural Press, 6-7.

Philippe, S. (1989). Les Barricades. Architectural Review, 186 (1110, August), 84-86.

Price, R. (1986). Documents on the French Revolution of 1848. London: Macmillan Press.

Przyblyski, P. (2001). Revolution at a Standstill: Photography and the Paris Commune of 1871. Yale French Studies (101), 54-78.

Rancière, J. (1998). Disagreement: Politics and Philosophy. Minneapolis: University of Minnesota Press.

Rancière, J. (2004). The Politics of Aesthetics. London: Continuum.

Traugott, M. (1978). Reconceiving Social Movements. Social Problems, 26 (1, October), 38-49.

Traugott, M. (1985). Armies of the Poor. Determinants of Working-Class Participation in the Parisian Insurrection of June 1848. New Jersey: Princeton University Press.

Traugott, M. (1993). Barricades as repertoire: Continuities and discontinuities in the history of French contention. Social Science History, 17 (2).

van Ginneken, J. (1992). Crowds, psychology, and politics 1871-1899. Cambridge: Cambridge University Press. 